\title{
Ant Species Richness Variation Mediated by Seasonality in Two Ant-Acacias from Oaxaca, Mexico
}

\author{
Sandra Luz Gómez-Acevedo* ${ }^{\circledR}$, Javier Martínez-Toledo \\ Unidad de Morfología y Función, Facultad de Estudios Superiores Iztacala, Universidad Nacional Autónoma de México, \\ Mexico City, México \\ Email: *sanluza@unam.mx
}

How to cite this paper: Gómez-Acevedo, S.L. and Martínez-Toledo, J. (2021) Ant Species Richness Variation Mediated by Seasonality in Two Ant-Acacias from Oaxaca, Mexico. Open Journal of Ecology, 11, 24-31.

https://doi.org/10.4236/oje.2021.111002

Received: November 16, 2020

Accepted: January 1, 2021

Published: January 4, 2021

Copyright $\odot 2021$ by author(s) and Scientific Research Publishing Inc. This work is licensed under the Creative Commons Attribution-NonCommercial International License (CC BY-NC 4.0). http://creativecommons.org/licenses/by-nc/4.0/

\section{Open Access}

\begin{abstract}
Climatic conditions affect the richness of ants resulting in number variation throughout the year. The ants present in the Neotropical system Acacia-Pseudomyrmex have been previously studied considering only one sampling season. In contrast, in this study we analyze the richness in two ant-acacia systems during the rainy and dry seasons. The study was carried out on a plot located in the state of Oaxaca, Mexico where 14 ant species, 3 mutualistic and 11 non-mutualistic were found, of which 2 represent new records for the state. Ant species number differed between ant-acacia species and between seasons. The highest richness was recorded in Acacia hindsii in both rainy and dry seasons, corresponding with a low-reward host. During the dry season, $A$. hindsii represents a highly valuable resource. This study shows that the neotropical system is much more dynamic than it has been previously considered and offers a valuable opportunity for subsequent ecological studies for a better understanding of this complex system.
\end{abstract}

\section{Keywords}

Dolichoderinae, Formicinae, Myrmicinae, Pseudomyrmex

\section{Introduction}

Several species of plants have evolved along with some insects, establishing a defensive mutual association [1]. Among the most representative examples of this, is the Neotropical mutualistic system Acacia-Pseudomyrmex and involves 15 species of myrmecophytic acacias and 10 species of ants, known as the Pseudomyrmex ferrugineus group [2] [3] [4]. Mutualistic ants increase their hosts' fit- 
ness by protecting them from herbivores and climbing lianas. As a consequence of such interaction, a high morphological specialization has been generated in both participants, that is, the mutualistic ants live in spinescent stipules called domatia; the pupae are fed with the Beltian bodies, which are food bodies produced at the apex of the leaflets; and the workers feed on the extrafloral nectar, which contains invertase, the enzyme responsible of sucrose hydrolysis. It is important to mention that the ants lack invertase in their digestive system, so the nectar composition has been considered as specific for such ant-group [2] [3] [5] [6] [7].

For this reason, the idea that only mutualistic ants inhabit the domatia of swollen-thorn acacias has been considered for a long time. Nevertheless, the resources involved (domatia, Beltian bodies and extrafloral nectar) are attractive to non-mutualistic species that exploit them without offering benefits in return and are considered as parasites of this mutualism [6] [8] [9]. The presence of non-mutualistic ants has recently been reported within the domatia of the Neotropical ant-acacias systems, such as species from the $P$. gracilis group and the $P$. subtilissimus group, as well as Camponotus planatus (Roger), who have independently developed an association with these plants and may be cohabiting together with the mutualistic ants [6] [9]-[14].

In particular, it has been found that Mexican ant-acacias, like A. mayana in Veracruz, A. chiapensis, A. collinsii, A. cornigera and A. mayana in Oaxaca, may be inhabited by both mutualistic $(\sim 76 \%)$ and non-mutualistic ants $(\sim 24 \%)$, which are located mainly in the lower parts of the plants [9] [10] [11] [14], or also inhabited by non-mutualistic ants only, like A. cedilloi in Quintana Roo [11]. In Central America there are reports of coexistence among the mutualistic Pseudomyrmex ferrugineus (F. Smith) with the non-mutualistic Camponotus planatus in Guatemala, in plants of Acacia cornigera and $A$. hindsii, as well as $P$. flavicornis (F. Smith) with the non-mutualistic P. subtilissimus (Emery) on Costa Rican acacias [15] [16].

All of these reports have been made considering only one sampling season and one sampling site, nevertheless studies focused on ants indicate that richness is a function of environmental parameters such as precipitation, temperature and seasonality [17] [18]. Until now, for the Acacia-Pseudomyrmex system no study has been performed that contemplates at least two seasons in order to evaluate possible changes in the composition of the ant species inhabitants. Considering the above, the present study was carried out with the purpose of analysing the myrmecofauna present in two ant-acacias, Acacia cornigera and $A$. hindsii, in one plot of Oaxaca, which is one of the two Mexican states with the highest biological diversity. The intention was to examine the presence of both mutualistic and non-mutualistic ants in the plants under study in two seasons (rainy and dry), and even if the ants occupy the ant-acacias as nesting sites, in order to provide updated information on the subject. The questions of this research were: 1) are the two ant-acacias occupied by mutualistic ants only? 2) are they occupied by the same ant species along two seasons of the year? and 3) the ant species nest in the two ant-acacias? 


\section{Materials and Methods}

The study was conducted in a plot of Guadalupe Victoria, located in the Municipality of Santiago Pinotepa Nacional, Oaxaca $\left(16^{\circ} 20^{\prime} \mathrm{N}, 98^{\circ} 03^{\prime} \mathrm{W}\right)$. The primary vegetation in the region includes rainforest, but there are some areas of secondary vegetation (grasslands and paddocks) as a result of agriculture and expansion of urban areas. In these last areas, Acacia cornigera and A. hindsii inhabit and coexist, growing preferably in disturbed sites. Both are species that present the greatest distribution among the Neotropical ant-acacias.

Ant collections were carried out during the months of November 2014 (rainy season) and March 2015 (dry season) in all ant-acacias located in the plot, that is, in three individuals of Acacia cornigera and four individuals of $A$. hindsii. The conditions of rainfall and temperatures in each season are indicated in $\mathrm{Ta}$ ble 1 . Ants were collected directly from each acacia by cutting off the entire domatium. For each acacia individual, 10 - 15 domatia were cut and fixed in 70\% ethanol and then reviewed under a stereoscopic microscope Labomed $4 \mathrm{Z}$. The number of immature (eggs, larvae and pupae), workers and reproductives were counted in order to appreciate the social structure of each species of ant and as evidence that the ants inhabit the ant-acacias's domatia. Some specimens were mounted for later identification.

\section{Results}

\subsection{Total Richness}

A total of 14 species of ants were collected, belonging to six genera and four subfamilies. Pseudomyrmecinae was the subfamily with the largest number of species, with 6 taxa from the Pseudomyrmex genus, of which only 3 were mutualistic. Myrmicinae was the second subfamily with 4 species in 2 genera. The subfamilies Dolichoderinae and Formicinae presented two species each one in two and one genera respectively (Table 2).

\subsection{Seasonal Richness}

Ant species richness differed between ant-acacia species and between seasons. A higher number of ant species was found in Acacia hindsii than in A. cornigera. In the rainy season, the mutualistic ant found in both ant-acacia species was Pseudomyrmex ferrugineus, this was the only ant species present on Acacia cornigera, while on $A$. hindsii two additional non-mutualistic species were found. In the dry season, the mutualistic species $P$. peperi (Forel) was present in

Table 1. Rainfall conditions (in millimeters) and temperature (in Celsius degrees) in Santiago Pinotepa Nacional, Oaxaca. The minimum ( $\min )$ and maximum (max) values of temperature are indicated.

\begin{tabular}{ccccc}
\hline Month & Rainfall $(\mathrm{mm})$ & $\mathrm{T}^{\bullet} \mathrm{C}$ & $\mathrm{T}^{\bullet} \mathrm{C}(\mathrm{min})$ & $\mathrm{T}^{\bullet} \mathrm{C}(\max )$ \\
\hline March & 0 & 27.2 & 18.6 & 35.8 \\
November & 19 & 26.5 & 19.4 & 33.7 \\
\hline
\end{tabular}


Table 2. List of ants collected. Mutualistic species are indicated by an asterisk. For all taxa, the total number of individuals are indicated above the parenthesis. The number of immatures, workers and reproductive is indicated in that order within the parenthesis.

\begin{tabular}{|c|c|c|c|c|c|}
\hline \multirow{2}{*}{ Subfamily } & \multirow{2}{*}{ Species } & \multicolumn{2}{|c|}{ Rainy Season } & \multicolumn{2}{|c|}{ Dry Season } \\
\hline & & A. cornigera & A. hindsii & A. cornigera & A. hindsii \\
\hline \multirow{2}{*}{ Dolichoderinae } & Aztecasp. & & & & $\begin{array}{c}1 \\
(0,1,0)\end{array}$ \\
\hline & Tapinoma sp. & & & & $\begin{array}{c}26 \\
(0,26,0)\end{array}$ \\
\hline \multirow{2}{*}{ Formicinae } & $\begin{array}{l}\text { Camponotus } \\
\text { sp. } 1\end{array}$ & & & & $\begin{array}{c}1 \\
(0,1,0)\end{array}$ \\
\hline & $\begin{array}{c}\text { Camponotus } \\
\text { sp. } 2\end{array}$ & & & & $\begin{array}{c}2 \\
(0,2,0)\end{array}$ \\
\hline \multirow{4}{*}{ Myrmicinae } & $\begin{array}{l}\text { Cephalotes } \\
\text { minutus }\end{array}$ & & & & $\begin{array}{c}4 \\
(0,4,0)\end{array}$ \\
\hline & $\begin{array}{l}\text { Cephalotes } \\
\text { scutulatus }\end{array}$ & & & & $\begin{array}{c}2 \\
(0,2,0)\end{array}$ \\
\hline & $\begin{array}{c}\text { Crematogaster } \\
\text { larreae }\end{array}$ & & $\begin{array}{c}42 \\
(0,42,0)\end{array}$ & & $\begin{array}{c}35 \\
(0,35,0)\end{array}$ \\
\hline & $\begin{array}{c}\text { Crematogaster } \\
\text { sp. }\end{array}$ & & & & $\begin{array}{c}1 \\
(0,1,0)\end{array}$ \\
\hline \multirow{6}{*}{ Pseudomyrmecinae } & $\begin{array}{l}\text { Pseudomyrmex } \\
\text { ferrugineus }\end{array}$ & $\begin{array}{c}522 \\
(425,86,11)\end{array}$ & $\begin{array}{c}155 \\
(80,64,11)\end{array}$ & & \\
\hline & $\begin{array}{l}\text { Pseudomyrmex } \\
\text { gracilis bicolor }\end{array}$ & & $\begin{array}{c}4 \\
(0,4,0)\end{array}$ & & $\begin{array}{c}3 \\
(0,3,0)\end{array}$ \\
\hline & $\begin{array}{c}\text { Pseudomyrmex } \\
\text { nigropilosus }\end{array}$ & & & & $\begin{array}{c}3 \\
(0,3,0)\end{array}$ \\
\hline & $\begin{array}{c}\text { Pseudomyrmex } \\
\text { pallidus }\end{array}$ & & & $\begin{array}{c}8 \\
(0,8,0)\end{array}$ & \\
\hline & $\begin{array}{c}\text { Pseudomyrmex } \\
\text { peperi }^{*}\end{array}$ & & & $\begin{array}{c}334 \\
(239,95,0)\end{array}$ & $\begin{array}{c}778 \\
(495,269,14)\end{array}$ \\
\hline & $\begin{array}{c}\text { Pseudomyrmex } \\
\text { veneficus }\end{array}$ & & & & $\begin{array}{c}3 \\
(0,3,0)\end{array}$ \\
\hline
\end{tabular}

both acacias; additionally, one non-mutualistic ant from the same genus was also found on $A$. cornigera. On $A$. hindsii, besides $P$. peperi, another mutualistic species $(P$. veneficus Wheeler) and ten non-mutualistic species were found (Table 2).

\subsection{Social Ants Structure}

With regard to castes, immature, workers and reproductives were found for two mutualistic species ( $P$. ferrugineus and $P$. peperi), while for the third mutualistic ( $P$. veneficus) and for all non-mutualistic species only workers were found. In the rainy season, the number of individuals of ants, including immature, workers and reproductives of all species involved, was greater for A. cornigera (522) 
than for $A$. hindsii (201), but in the dry season the opposite occurred, the total number of individuals was higher for $A$. hindsii (859) than for $A$. cornigera (342). In all cases, the greatest contribution of individuals was from the mutualistic ants (Table 2).

\section{Discussion}

Oaxaca is recognized as the wealthiest state in Mexico in terms of flora and fauna biodiversity [19]. Regarding ant richness, a total of 108 taxa have been reported, which is a small number compared to the geographical dimensions and complex orography of the state [18]. In the present study, 14 species were found, of which only Cephalotes scutulatus (F. Smith) and Crematogaster larreae (Buren), both from the subfamily Myrmicinae, represent new records for Oaxaca, thus increasing the number of ant species to 110 for the state. In particular, for the group Pseudomyrmex ferrugineus, Varela-Hernández et al. [20] reported a total of four species in Oaxaca ( $P$. ferrugineus, $P$. mixtecus, $P$. peperi and $P$. veneficus), nevertheless in our study only three of them were found, but this could be due to the sampling area, just in one locality.

Ants are one of the most important groups of terrestrial organisms, their importance and contribution to ecological processes has been more than proven, and therefore represent a key to the understanding of ecosystems [18]. Temperature, precipitation and seasonality are included among the factors that affect ant richness [17] [18]. In previous studies where ant species richness has been tested as a function of seasonality, Sousa-Souto et al. [18] found variations with respect to drought and rainy seasons, that is, for arboreal ants in Brazil, a greater richness was reported in the rainy season, in which the vegetation is abundant, and the canopies of the trees are connected.

Contrary to the above, in the present study the highest richness of ants was found during the dry season, where 13 species (92.8\%) were recorded, compared to three species in the rainy season. It is also important to note that of the 13 species, 11 (78.6\%) were found exclusively on $A$. hindsii. The fact that $A$. hindsii presents the greatest richness of non-mutualistic ants in comparison to $A$. cornigera, could be in agreement with the proposal of Heil et al. [21], who classified the ant-acacias as high- or low-reward hosts. Following this scheme, A. cornige$r a$ is a high-reward host, which results in an intense patrol of its resident ants, in such a way that species of ants outside of this mutualism are driven away with greater efficiency and the plants have a greater protection against the exploitation of resources. On the contrary, $A$. hindsii is a low-reward host and therefore has a relaxed patrol of its host ants, allowing greater proportion of ants that do not belong to the mutualistic system to be present.

In the present study, for 12 ant species (11 of them non-mutualistic) only workers were registered, ranging from a single individual to 42 , which indicates that these taxa only occasionally occupy these plants or do not nest in their domatia. On the contrary, for the mutualistic ants Pseudomyrmex ferrugineus and 
P. peperi, individuals of all castes were found, although with differences in the two seasons. During the rainy season, the mutualistic ant present in both acacias species was $P$. ferrugineus, which presented a higher number of immature and workers in $A$. cornigera than in $A$. hindsii. During the dry season, the mutualistic $P$. peperi was inhabiting the two ant-acacias and presented a number of workers similar to that observed in the rainy season for $P$. ferrugineus in $A$. cornigera, although with a lower number of immatures. However, in $A$. hindsii a higher number of immatures, workers and reproductives was recorded, suggesting that despite the climatic conditions and despite being a low-reward host, $P$. peperi finds in this ant-acacia the adequate conditions to maintain its colonies, as indicated also by the number of reproductives found. In this regard, there is evidence for and against the social structure of ants being affected by the availability of resources, which can be reflected both in the propagule size and in the number of queens [22] [23] [24].

\section{Conclusions}

This study shows that for the ant-acacias in the study area there is a mutualistic ant change depending on seasonality and in consequence on the resources offered by the plant, that is, during the rainy season Pseudomyrmex ferrugineus occupies both ant-acacias. During this season the production of new leaves increases and in consequence also the production of food bodies, which are used exclusively to feed the larvae, so it is not surprising that a greater number of immatures are found in the domatia of this ant-acacia. According to this, $P$. ferrugineus could be considered as an ant guest of high-demand. During the dry season, when the production of leaves and Beltian-bodies is diminished, it seems the ant-acacias cannot support $P$. ferrugineus, but they can maintain $P$. peperi, which could be considered as a low-demand ant guest.

This study shows that during the dry season the myrmecophytic acacias and in particular $A$. hindsii are a highly valuable and useful resource not only for resident ants, but also for the rest of the myrmecofauna present, which are likely to venture to explore ant-acacias in the search of food resources. It is important to note that although the extrafloral nectar composition is particularly special for resident ants, it could represent a highly profitable resource during the dry season.

Finally, it is possible to appreciate that the composition and social structure of the mutualistic and non-mutualistic ants present in these two ant-acacias, exhibit a greater dynamism than previously considered for the Neotropical Acacia-Pseudomyrmex system, offering a valuable opportunity to perform further ecological as well as molecular studies, for a better understanding of this complex system.

\section{Acknowledgements}

This research was carried out thanks to the support of the project PAPCA 
(FESI-DIP-PAPCA-2014-38) and the Program UNAM-DGAPA-PAPIIT (IA203515, IN217217). The authors express their gratitude to the Ávila family, for their hospitality and the capture of specimens on their plot in Santiago Pinotepa Nacional, Oaxaca. We also thank Gabriela Castaño Meneses and Miguel Vásquez-Bolaños for the identification of some ant species and Erika Aguirre-Planter for her English support. This paper was written during a sabbatical leave of SLG-A.

\section{Conflicts of Interest}

The authors declare no conflicts of interest regarding the publication of this paper.

\section{References}

[1] Hölldobler, B. and Wilson, E.O. (1990) The Ants. Harvard University Press, Cambridge.

[2] Janzen, D.H. (1974) Swollen-Thorn Acacias of Central America. Smithsonian Contributions to Botany, No. 13, 1-131. https://doi.org/10.5962/bhl.title.123341

[3] Ward, P.S. (1993) Systematic Studies on Pseudomyrmex Acacia-Ants (Hymenoptera: Formicidae: Pseudomyrmecinae). Journal of Hymenoptera Research, 2, 117-168.

[4] Ward, P.S. (2017) A Review of the Pseudomyrmex ferrugineus and Pseudomyrmex goeldii Species Groups: Acacia-Ants and Relatives (Hymenoptera: Formicidae). Zootaxa, 4227, 524-542. https://doi.org/10.11646/zootaxa.4227.4.3

[5] Heil, M., Baumann, B., Kruger, R. and Linsenmair, K.E. (2004) Main Nutrient Compounds in Food Bodies of Mexican Acacia Ant-Plants. Chemoecology, 14, 45-52. https://doi.org/10.1007/s00049-003-0257-x

[6] Kautz, S., Lumbsch, H.T., Ward, P.S. and Heil, M. (2009) How to Prevent Cheating: A Digestive Specialization Ties Mutualistic Plant-Ants to Their Ant-Plant Partners. Evolution, 63, 839-853. https://doi.org/10.1111/j.1558-5646.2008.00594.x

[7] Ward, P.S. and Branstetter, M.G. (2017) The Acacia Ants Revisited: Convergent Evolution and Biogeographic Context in an Iconic Ant/Plant Mutualism. Proceedings of the Royal Society B, 284, Article ID: 20162569. https://doi.org/10.1098/rspb.2016.2569

[8] Janzen, D.H. (1975) Pseudomyrmex nigropilosa: A Parasite of a Mutualism. Science, 188, 936-937. https://doi.org/10.1126/science.188.4191.936

[9] Clement, L.W., Köppen, S.C., Brand, W.A. and Heil, M. (2008) Strategies of a Parasite of the Ant-Acacia Mutualism. Behavioral Ecology and Sociobiology, 26, 953-962. https://doi.org/10.1007/s00265-007-0520-1

[10] Raine, N.E., Gammans, N., Macfadyen, I.J., Scrivner, G.K. and Stone, G.N. (2004) Guards and Thieves; Antagonistic Interactions between Two Ant Species Coexisting on the Same Ant-Plant. Ecological Entomology, 29, 345-352. https://doi.org/10.1111/j.0307-6946.2004.00608.x

[11] Castaño-Meneses, G., Gómez-Acevedo, S.L. and Eguiarte-Fruns, L.E. (2008) Hormigas (Hymenoptera: Formicidae) asociadas a acacias mirmecófilas (Leguminosae: Mimosoideae) en México y Centroamérica. In: Estrada, E.G., Equihua, A., Padilla, J.R. and Mendoza, A., Eds., Entomología Mexicana, Vol. 7, XLIII, Sociedad Mexicana de Entomología, Texcoco, 105-110.

[12] Heil, M., Orona-Tamayo, D., Eilmus, S., Kautz, S. and González-Teuber, M. (2010) 
Chemical Communication and Coevolution in an Ant-Plant Mutualism. Chemoecology, 20, 62-74. https://doi.org/10.1007/s00049-009-0036-4

[13] Heil, M., Barajas-Barron, A., Orona-Tamayo, D., Wielsch, N. and Svatos, A. (2014) Partner Manipulation Stabilises a Horizontally Transmitted Mutualism. Ecology Letters, 17, 185-192. https://doi.org/10.1111/ele.12215

[14] Gómez-Acevedo, S., Trujillo, C.O., Castaño-Meneses, G., Martínez, T.J., Callejas-Chavero, A., Cueva del Castillo, M.R. and Tapia-Pastrana, F. (2015) Mirmecofauna asociada a acacias mirmecófilas en Veracruz y Oaxaca, México. In: Castaño-Meneses, G., Vásquez-Bolaños, M., Navarrete-Heredia, J.L., Quiroz-Rocha, G.A. and Alcalá-Martínez, I., Eds., Avances de Formícidae de México, Universidad Nacional Autónoma de México, and CUCBA, Universidad de Guadalajara, Mexico 171-177.

[15] Wheeler, W.M. (1913) Observations on the Central America Acacia Ants. 2nd International Congress of Entomology, Oxford, August 1912, Volume II, 109-139.

[16] Ward, P.S. (1989) Systematics Studies on Pseudomyrmecinae Ants: Revision of the Pseudomyrmex oculatus and P. subtilissimus Species Groups, with Taxonomic Comments on Other Species. Quaestiones Entomologicae, 25, 393-468.

[17] Pereira, L.P.C., Almeida, F.S., Vargas, A.B., Araújo, M.S., Mayhé-Nunes, A.J. and Queiroz, J.M. (2016) Seasonal Analysis of Taxonomic and Functional Diversity of Poneromorph Ant Assemblages in the Amazon Forest. Sociobiology, 63, 941-949. https://doi.org/10.13102/sociobiology.v63i3.1053

[18] Sousa-Souto, L., Figuiredo, P.M.G., Ambrogi, B.G., Oliveira, A.C.F., Ribeiro, G.T. and Neces, F.S. (2016) Composition and Richness of Arboreal Ants in Fragments of Brazilian Caatinga: Effects of Secondary Succession. Sociobiology, 63, 762-769. https://doi.org/10.13102/sociobiology.v63i2.909

[19] Galindo, C. (2010) Áreas comunitarias protegidas en Oaxaca. In: Carabias, J., Sarukhán, J., de la Maza, J. and Galindo, C., Eds., Patrimonio natural de México. Cien casos de éxito, Comisión Nacional para el Conocimiento y uso de la Biodiversidad, México, 20.

[20] Varela-Hernández, F., Riquelme, F., Reyes-Prado, H. and Jones, R.W. (2016) New Records of Ants from Oaxaca, Southern Mexico. Southwestern Entomologist, 41, 705-714. https://doi.org/10.3958/059.041.0313

[21] Heil, M., González-Teuber, M., Clement, L.S., Kautz, S., Verhaagh, M. and Silva, B.J.C. (2009) Divergent Investment Strategies of Acacia Myrmecophytes and the Coexistence of Mutualists and Exploiters. Proceedings of the National Academy of Sciences of the United States of America, 106, 18091-18096.

https://doi.org/10.1073/pnas.0904304106

[22] Backus, V.L. and Herbers, J.M. (1992) Sexual Allocation Ratios in Forest Ants: Food Limitation Does Not Explain Observed Patterns. Behavioral Ecology and Sociobiology, 30, 425-429. https://doi.org/10.1007/BF00176178

[23] Foitzik, S., Backus, V.L., Trindl, A. and Herbers, J.M. (2004) Ecology of Leptothorax Ants: Impact of Food, Nest Sites and Social Parasites. Behavioral Ecology and Sociobiology, 55, 484-493. https://doi.org/10.1007/s00265-003-0718-9

[24] VanWeelden, M.T., Bennett, G. and Buczkowski, G. (2015) The Effects of Colony Structure and Resource Abundance on Food Dispersal in Tapinoma sessile (Hymenoptera: Formicidae). Journal of Insect Science, 15, 1-7.

https://doi.org/10.1093/jisesa/ieu176 